\title{
Fenomena Membolos Sekolah Di Madrasah Aliyah At-Taufiq Sigaraja Sebagai Bentuk Perilaku Menyimpang dan Potensinya Sebagai Sumber Belajar Sosiologi di SMA
}

\author{
Oleh: \\ Aizil Mamnun, Luh Putu Sendratari, I Ketut Margi
}

\author{
Jurusan Pendidikan Sosiologi \\ Universitas Pendidikan Ganesha \\ Singaraja, Bali
}
e-mail: aizil.mamnun@undiksha.ac.id, putu.sendratari@undiksha.ac.id, ketut.margi@undiksha.ac.id,

\section{PENDAHULUAN}

Pendidikan merupakan proses penyiapan subyek didik menuju manusia yang bertanggungjawab. Pendidikan dalam Undang-Undang Nomer 20 Tahun 2003 merupakan salah satu faktor penting untuk menciptakan dan mengembangkan potensi peserta didik agar dapat menjadi manusia yang beriman, dan bertaqwa kepada Tuhan Yang Maha Esa, berakhlak mulia, sehat, berilmu, cakap, kreatif, mandiri, dan menjadi warga negara yang demokratis serta bertanggungjawab. Salah satunya yaitu dengan adanya sekolah sebagai lembaga sosial dan pendidikan yang dipilih dan ditempatkan diantara sistem kelembagaan yang sudah ada.

Sekolah merupakan sebuah lembaga formal yang digunakan peserta didik untuk menimba ilmu dalam mengembangkan kemampuan, bakat dan minatnya. Sekolah juga mengajarkan peserta didik bagaimana mengaplikasikan ilmu pengetahuan dalam kehidupan sehari-hari dan membentuk karakter yang baik dalam diri peserta didik. Sekolah memiliki bermacam-macam kurikulum, salah satunya adalah bermuatan umum dan bermuatan agama. Perbedaannya terletak pada penerapan kurikulumnya.

Kurikulum bermuatan agama memiliki peranan yang penting dalam pembentukan sikap dan kepribadian peserta didik, di lingkungan sekolah maupun masyarakat. Peserta didik yang memiliki latar belakang pendidikan agama seharusnya memiliki pengetahuan dan pemahaman yang dalam terhadap ajaranajaran agama dan dapat menjalankan semua ajaran agamanya, sehingga para peserta didik akan menolak dan bersikap negatif terhadap perilaku-perilaku yang tidak sesuai dengan ajaran agamanya. Namun jika dilihat dari kondisi lingkungan masyarakat saat ini, pendidikan agama tidak menjamin terbentuknya perilaku yang baik dalam diri peserta didik. Hal ini bisa dilihat dari perilaku sebagian peserta didik di salah satu lembaga pendidikan formal yang ada di Singaraja yaitu Madrasah Aliyah At-Taufiq.

\section{Madrasah Aliyah At-Taufiq} merupakan salah satu lembaga pendidikan formal berstatus swasta yang terletak di jalan Hasannudin No.28 A Singaraja, Bali, yang memiliki visi membentuk insan yang berkualitas dalam iman dan taqwa (IMTAQ) dan ilmu pengetahuan dan teknologi (IPTEK). Jika dilihat dari visi Madrasah Aliyah At-Taufiq, seharusnya peserta didik memiliki perilaku yang sesuai dengan visi Madrasah. Namun kenyataan yang ada di lapangan masih terdapat pelanggaran-pelanggaran yang dilakukan peserta didik, dalam hal ini yaitu membolos. Berdasarkan hasil wawancara dengan Ibu Evi Nurmasita, (31 tahun) mengatakan bahwa "hampir setiap 
harinya ada saja siswa yang membolos, kecuali pada waktu ujian".

Berdasarkan buku catatan pelanggaran peserta didik pada bulan Agustus 2017 sampai dengan bulan Maret 2018 tercatat $50 \%$ peserta didik melakukan perilaku menyimpang dalam bentuk membolos yang terbagi dalam tiga kelas yaitu kelas X $10 \%$, XI 15\%, dan XII $25 \%$. . Perilaku menyimpang (membolos) biasanya dilakukan oleh peserta didik dengan alasan bahwa keadaan lingkungan sekolah terlalu membosankan, pernyataan tersebut dipertegas dengan hasil wawancara dengan Aditya (17 tahun) yang mengatakan "Bosan bu di kelas ngantuk juga karena gurunya kalau mengajar Cuma gitu-gitu saja". Alasan tersebut bisa dijadikan sebagai gambaran awal mengenai salah satu faktor terjadinya perilaku membolos.

Membolos menurut Gunarsa, (2006: 31) adalah pergi meninggalkan sekolah tanpa adanya alasan yang tepat pada saat jam pelajaran dan tidak izin terlebih dahulu kepada pihak sekolah. Kartini Kartono (dalam Tutiona, 2016: 31) membolos yaitu ketidakhadiran peserta didik tanpa alasan yang tepat. Kebiasaan membolos yang dilkakukan peserta didik akan berdampak negatif pada dirinya antara lain dihukum, diskorsing, tidak dapat mengikuti ujian, bahkan bisa dikeluarkan dari sekolah.

Perilaku membolos merupakan suatu permasalahan yang perlu ditangani, hal ini dikarenakan perilaku membolos dianggap menggangu kegiatan belajar di sekolah dan juga menghambat tercapainya tujuan pendidikan nasional, yaitu mencerdaskan kehidupan bangsa. Oleh karena itu pihak sekolah harus lebih ketat lagi dalam membuat tata tertib yang ada di sekolah agar peserta didik tidak melakukan pelanggaran secara terus menerus terutama dalam hal membolos.

$$
\text { Untuk mengatasi perilaku }
$$

membolos Madrasah Aliyah At-Taufiq telah banyak melakukan penanganan kepada peserta didik yang melakukan perilaku membolos, namun nampaknya usaha-usaha yang dilakukan belum dapat dilaksanakan secara optimal.

Sumber belajar adalah segala sesuatu yang bisa digunakan untuk mendukung kegiatan belajar, termasuk sisem pendukung dan materi lingkungan pembelajaran (Musfiqon, 2012: 128). Dalam memberikan materi sosiologi guru Madrasah Aliyah At-Taufiq hanya mengacu pada lembar kerja siswa (LKS) sehingga peserta didik kurang peka dan kurang memahami permasalahanpermasalahan sosial yang terjadi di lingkungan sekitarnya. Padahal, banyak sekali permasalahan-permasalahan sosial yang bisa dijadikan sebagai sumber belajar sosiologi, salah satu nya perilaku membolos yang dilakukan peserta didik Madrasah Aliyah At-Taufiq pada materi penyimpangan sosial.

Berdasarkan penjelasan di atas, peneliti akan membuat hasil penelitian yang berjudul "Fenomena Membolos Sekolah Di Madrasah Aliyah At-Taufiq Sigaraja Sebagai Bentuk Perilaku Menyimpang dan Potensinya Sebagai Sumber Belajar Sosiologi di SMA".

Penelitian ini dapat dikaji dengan menggunakan beberapa teori yaitu; (1)Teori perilaku menyimpang. Perilaku menyimpang merupakan perilaku yang tidak sesuai dengan nilai dan norma yang berlaku di dalam masyarakat. Menurut Hisyam (2018:2) perilaku menyimpang seuatu tindakan yang dilakukan seseorang atau beberapa anggota masyarakat dengan secara sadar atau tidak sadar yang menentang dengan norma dan aturan yang telah disepakati bersama.

Perilaku menyimpang memiliki
beberapa bentuk yaitu, perilaku
menyimpang berdasrakan sifat dan
berdasarkan bentuk pelakunya. Perilaku
menyimpang berdasarkan sifat dibagi
menjadi dua yaitu bersifat negatif dan
bersikap positif. Sedangakan perilaku
menyimpang berdasarkan bentuk
pelakunya dibagi menjadi tiga yaitu,


penyimpangan individual, penyimpangan kelompok dan peyimpangan campuran (Hisyam, 2018: 10).

\section{(2) Teori Perilaku Membolos}

Membolos merupakan sebuah tindakan meninggalkan sekolah tanpa adanya alasan yang jelas. Menurut Kartini Kartono (dalam Tutiona, 2016: 69) mengungkapkan bahwa perilaku membolos adalah ketidakhadiran peserta didik tanpa adanya izin dari orang tua atau sekolah, meninggalkan sekolah saat kegiatan belajar sedang berlangsung dan terlambat datang ke sekolah dengan sengaja. Perilaku membolos terjadi kerena disebabkan oleh beberapa faktor antara lain;

a. Faktor internal, yaitu faktor yang berasal dari dalam diri peserta didik. karakter peserta didik yang memang suka membolos dan menjadikan sekolah sebagai tempat berkumpulnya mereka dengan teman-teman.

b. Faktor eksternal, yaitu faktor yang berasal dari luar lingkungan, seperti faktor lingkungan keluarga yang kurang peduli terhadap pendidikan anak, guru yang tidak konsisten sehingga dapat mempengaruhi kegiatan belajar mengajar di kelas, teman yang selalu memberi pengaruh tidak baik dan sarana prasaran yang minim. Menurut Prayitno dan Amti (2004: 98) faktor penyebab membolos sekolah yaitu;

1. Tidak senang dengan perilaku guru;

2. Merasa kurang mendapat perhatian guru;

3. Proses belajar mengajar yang membosankan;

4. Kurang berminat dalam mata pelajaran;

5. Kurang adanya motivasi belajar dari orang tua.

Perilaku membolos memiliki berbagai macam bentuk. Menurut Prayitno dan Amti (2004: 10) terdapat empat bentuk perilaku membolos yaitu, (1) peserta didik absen tanpa ada izin dari orag tua atau pimpinan sekolah; (2) Peserta didik meninggalakan sekolah pada saat kegiatan belajar mengajar sedang berlangsung; dan (3) terlambat masuk kelas dengan sengaja.
3. Teori Penangan Perilaku Membolos. Penanganan merupakan tidakan yang dilakukan untuk mengatasi permasalah yang terjadi pada individu maupun kelompok. Damayanti, (2012: 57) menyebutkan bahwa ada beberapa pola penangan yang dapat digunakan untuk meminimalisir perilaku membolos yaitu,

a. Pendekatan disiplin merujuk pada tata tertib yang berlaku di sekolah beserta sanksi-sanksi yang ada. Pelaksanaan aturan yang ada di sekolah juga harus selalu konsisten, maksudnya adalah satu dengan yang lainnya harus saling berhubungan dan tidak bertentangan dengan aturan yang ada atau bisa disebut dengan taat.

b. Seorang pendidik harus bisa menciptakan suasana kelas yang menyenangkan dengan berkreasi dan berinovasi supaya siswa tidak mudah jenuh. Misalnya pemberian reward bagi siswa yang menunjukan perubahan perilaku kearah yang lebih baik.

4. Teori Sumber Belajar. Musfiqon (2012: 128) menjelaskan bahwa sumber belajar adalah segala sumber pendukung untuk kegiatan belajar, termasuk sistem pendukung dan materi serta lingkungan pembelajaran. Sumber belajar mempunyai potensi yang cukup besar untuk mengembangkan dan memperjelas materi yang akan di sampaikan kepada peserta didik. seperti yang dikatan oleh Adipurnomo (2006: 6) sumber belajar dapat berguna untuk

1. Menimbulkan kegairahan belajar.

2. Memungkinkan adanya interaksi yang lebih langsung antara peserta didik dengan lingkungan.

3. Memberikan kesempatan peserta didik untuk mencari pengalam.

4. Menjadikan peserta didik lebih mandiri.

5. Menghilangkan kekacauan penafsiran.

Tujuan yang ingin dicapai

dalam penenlitian ini antara lain: (1) untuk mengetahui faktor-faktor penyebab siswa membolos; (2) untuk mengetahui bentuk-bentuk perilaku membolos yang ada di Madrasah Aliyah At-Taufiq Singaraja; (3) untuk mengetahui pola penanganan yang dilakukan pihak Madrasah terhadap peserta didik yang melakukan perilaku 
menyimpang dalam bentuk membolos; dan (4) untuk mengetahui aspekaspek dalam fenomena membolos sebagai sumber belajar sosiologi di SMA.

\section{METODE}

Metode yang dilakukan dalam penelitian ini yaitu metode deskriptif kualitatif yang digunakan untuk memperoleh informasi mengenai fenomena membolos sekolah di Madrasah Aliyah At-Taufiq sebagai bentuk perilaku menyimpang dan potensinya sebagai sumber belajar sosiologi di SMA. Penelitian ini dilakukan di Madrasah Aliyah At-Taufiq Singaraja, Bali. Hal ini dikarenakan Madrasah Aliyah At-Taufiq merupakan salah satu sekolah swasta yang tingkat pelanggaran tata tertib dalam bentuk membolos sangat tinggi.

biasa digunakan sumber data yang deskriptif kualitatif ialah sebagai berikut: (1) Narasumber, dalam penelitian ini yang menjadi narasumber atau informan adalah peserta didik yang melakukan tindakan membolos sekolah, Kepala Madrasah dan guru Madrasah Aliyah At-Taufiq; (2) Aktivitas, dalam penelitian ini aktivitas yang dilakukan oleh informan di sekolah; (3) Tempat atau lokasi, penelitian ini berlokasi di Madarasah Aliyah At-Taufiq Singaraja yang beralamat di Jl. Hasannudin No.28 A; (4) Gambar dan dokumen, dalam mendapatkan data dengan mengambil gambar peristiwa atau kejadian yang diteliti, sedangkan untuk dokumen peneliti menggunkan jenis data kuatitaif berupa buku pelanggaran tata tertib siswa dan dokumen statistik sekolah seperti sarana dan prasaran sekolah sebagai penunjang data kualitatif yang didapatkan, dengan demikian memberikan bukti nyata dari hasil penelitian yang dilakukan.

Untuk mendapatkan data yang relevan tidak semua orang bisa dijadikan informan, sehingga pada penelitian ini peneliti menggunakan teknik purposive sampling dan teknik snowball hal ini bertujuan agar data yang diperoleh peneliti bisa lebih akurat dan jelas.

Dalam teknik pengumpulan data peneliti menggunakan metode observasi yang digunakan unutk mengamati aktivitas peserta didik selama penelitian serta mengamati penanganan yang dilakukan pihak Madrasah Aliyah AtTaufiq terhadap peserta didik yang membolos. Selanjutnya teknik wawancara yang ditujukan kepada peserta didik yang melakukan perilaku membolos dengan tujuan untuk mengetahui latar belakang penyebab peserta didik membolos dan pola penanganan yang dilakukan pihak Madrasah Aliyah At-Taufiq. Kemudian studi dokumen.

Menurut Miles dan Haberman (dalam Sugiyono, 2010:337) analisis data dalam penelitian kualitatif dilakukan dengan beberapa aktivitas yang terdiri dari, (1) Reduksi data. Dalam penelitian ini, peneliti hanya mengambil data-data penting yang memiliki keterkaitan dengan aspek-aspek yang diteliti; (2) Penyajian data. Dalam penelitian ini data yang diperoleh lebih banyak disajikan dalam bentuk uraian. Namun ada juga yang disajikan dalam bentuk bagan, tabel, hubungan antar kategori, dan lain sebagainya; (3) Penarikan kesimpulan. dalam penelitian ini, dilakukan dengan mengamati data yang diperoleh dari awal periode pengumpulan data.

Sementara itu, untuk mendapatkan keabsahan data agar dapat diakui kebenarannya secara objektif dalam penelitian ini, dilakukan dengan menggunakan teknik triangulasi yakni triangulasi teknik dan triangulasi sumber.

\section{HASIL DAN PEMBAHASAN Latar Belakang Peserta Didik Membolos

Membolos adalah ketidakhadiran peserta didik tanpa adanya alasan yang tepat, meninggalkan sekolah sebelum waktunya dan selalu datang terlambat. Berdasarakan hasil penelitian yang dilakukan terdapat dua faktor yang menjadi penyebab peserta didik Madrasah Aliyah At-Taufiq melakukan perilaku membolos. Faktor-faktor tersebut yaitu, faktor internal dan faktor eksternal. Faktor internal merupakan faktor yang berasal 
dari dalam diri, dimana peserta didik kurang memiliki semangat untuk belajar di sekolah sehingga mereka lebih memilih tidur atau bermain daripada berangkat ke se sekolah. Sedangkan faktor eksternal merupakan faktor yang berasal dari keluarga, teman dan lingkungan sekolah. Faktor keluarga ini yang dimaksud yaitu orang tua yang kurang perduli terhadap pendidikan anak secara tidak langsung akan membentuk sikap kurang semangat dalam diri peserta didik untuk pergi ke sekolah. Menghilangnya kontrol orang tua yang sibuk mengejar materi membuat peserta didik merasa kurang kasih sayang orang tua sehingga peserta didik menyalurkan energinya melalui kegiatan yang dianggap benar seperti membolos sekolah. Hal ini seperti yang diungkapan oleh Bapak Sahlan selaku Kepala Madrasah yang mengatakan bahwa "Orang tua peserta didik di sini rata-rata berkerja sebagai pedangang sehingga banyak peserta didik yang kurang mendapatkan perhatian penuh dari orang tua, orang tua mereka sibuk dengan pekerjaannya sehingga peserta didik sipasarahkan sepenuhnya ke pihak Madrasah".

Membolos karena pengaruh dari keluarga dialami oleh Adam (17 tahun). Adam merupakan salah satu peserta didik yang tingkat membolosnya sangat banyak. Orang tua Adam (17 tahun) dan Gamar (18 tahun) yang bekerja sebagai pedagang dari pagi hingga sore membuat mereka merasa kurang mendapatkan perhatian dan kasih sayang, sehingga mereka melakukan perilaku membolos untuk menyalurkan energinya dengan melakukan perbuatan yang dianggap benar.

Selain itu faktor yang berasal dari sekolah juga dapat menjadi penyebab peserta didik memolos sekolah, seperti guru. Menurut Sanjaya, (2009: 51) guru dalam proses pembelajaran di kelas memiliki peran penting terutama dalam membantu peserta didik untuk membangun sikap positif, membangkitkan rasa ingin tahu, mendorong kemandirian dan membuat suasana kelas menyenangkan. Namun di Madrasah Aliyah At-Tuafiq terdapat beberapa guru yang dianggap kurang mampu dalam menciptakan suasana kelas yang efektif dan menyenangkan. Hal ini dikarenakan cara mengajar guru yang terlalu membosankan dan membuat peserta didik tidak nyaman berada di dalam kelas. $\mathrm{Hal}$ ini seperti yang di ungkapakan oleh Nazar (16 tahun), Gamar (18 tahun), dan Rizky (17 tahun), mereka mengatakan bahwa ada beberapa guru yang cara mengajarnya menurut mereka sangat membosankan karena guru dianggap terlalu serius dalam menjelaskan materi, guru tersebut kurang ramah terhadap peserta didik dan metode yang digunakan hanya metode ceramah, sehingga peserta didik merasa bosan dan tidak nyaman berada di dalam kelas. Namun sebaliknya, jika guru tersebut mampu bersahabat, ramah dan mampu menciptakan suasana yang menyenangkan maka peserta didik akan nyaman berada di dalam kelas. Hal ini dikarenakan suasana kelas sangat berpengaruh terhadap motivasi belajar peserta didik.

Perilaku menyimpang peserta didik (membolos) Madarsah Aliyah At-Taufiq juga tidak bisa terlepas dari pengaruh teman sekelas, hal tersebut ditemukan pada beberapa peserta didik yang mengatakan bahwa peserta didik membolos karena ajakan dari teman. Seperti yang dialami oleh Akbar (18 tahun) yang selalu terpengaruh ajakan teman untuk membolos, hal itu dilakukan karena Akbar (18 tahun) tidak bisa menolak dengan alasan akan merasa tidak enak dan di angap tidak setia kawan.

Kemudian, minimnya sarana dan prasarana yang ada di Madrasah Aliyah At-Taufiq juga merupakan salah satu faktor penyebab peserta didik melakukan perilaku membolos. Dimana Madrasah Aliyah At-Taufiq tdak memiliki ruang kelas yang cukup sehingga peserta didik harus bergantian dalam menggunakan kelas. Misalnya seperti kelas XII harus belajar di ruang perpustakaan milik Madrasah Tsanawiyah dengan kondisi ruangan yang sempit dan tidak memiliki kursi sebagai 
tempat duduk. Sehingga peserta didik kurang nyaman di dalam kelas dan lebih memilih untuk pergi meninggalkan kelas.

\section{Bentuk-bentuk Perilaku Membolos Peserta Didik Madrasah Aliyah At- Taufiq}

Berdasarkan hasil peneltiian yang dilakukan peneliti terdapat beberapa bentuk perilaku membolos yang dilakukan peserta didik yaitu, terlambat, meninggalkan kelas di saat kegiatan belajar sedang berlangsung, pulang sebelum waktunya dan tidak masuk sekolah dengan alasan yang tidak jelas. Hal ini dapat dilihat pada tabel 1.1 sebagai berikut;

Tabel 1.1

Terlambat Tahun $2017-2018$

\begin{tabular}{|c|l|c|}
\hline NO & \multicolumn{1}{|c|}{ Kelas } & Terlambat \\
\hline 1 & Kelas X & 23 Peserta didik \\
\hline 2 & Kelas XI & 24 Peserta Didik \\
\hline 3 & Kelas XII & 14 Peserta didik \\
\hline & Total & 62 Peserta didik \\
\hline
\end{tabular}

Sumber: Buku Catatan Pelanggaran

Siswa Madrasah Aliyah

Dari Tabel $1.1 \mathrm{di}$ atas dapat dilihat bahwa bentuk perilaku membolos yang di lakukan peserta didik Madrasah Aliyah AtTaufiq yang pertama yaitu terlambat dengan jumlah 63 peserta didik pada tahun 2017 sampai 2018. Terlambat adalah datang ke sekolah lewat dari waktu yang di tentukan, oleh karena itu peserta didik yang datang terlambat dianggap membolos. Hal ini sesuai dengan yang dikatakan Kartini Kartono, 2003:21 dalam Tutiona (2016:69) bahwa selalu datang terlambat merupakan salah satu bentuk perilaku membolos.

Bentuk membolos lain yang terdapat di Madrasah Aliyah At-Taufiq yaitu tidak masuk sekolah tanpa adanya alasan yang jelas. Hal ini dapat dilihat pada Tabel 1.2 sebagai berikut:
Tabel 1.2

Tidak Masuk Sekolah Tanpa Izin/Alpa Tahun $2017-2018$

\begin{tabular}{|c|l|c|}
\hline NO & Kelas & $\begin{array}{c}\text { Bolos Jam } \\
\text { Pelajaran/Tidak } \\
\text { Ada izin }\end{array}$ \\
\hline 1 & Kelas X & 15 Peserta didik \\
\hline 2 & Kelas XI & 13 Peserta Didik \\
\hline 3 & Kelas XII & 10 Peserta didik \\
\hline \multicolumn{2}{|c|}{ Total } & 38 Peserta didik \\
\hline
\end{tabular}

Sumber: Buku Catatan Pelanggaran

Siswa Madrasah Aliyah At-Taufiq

Dari Tabel 1.2 di atas dapat dikatakan bahwa terdapat peserta didik yang sering tidak masuk sekolah dengan tidak adanya izin yang jelas dari orang tua atau pimpinan sekolah. Dalam periode Agustus 2017-Maret 2018 dapat ditemukan 38 peserta didik yang membolos sekolah atau biasa disebut dengan alpa.

Selain itu, bentuk perilaku membolos lain yang terdapat di Madrasah Aliyah At-Taufiq yaitu pergi meninggalkan kelas pada saat kegiatan belajar mengajar sedang berlangsung atau meninggalkan kelas sebelum waktunya. Hal ini dapat dilihat pada Tabel 1.3 sebagai berikut:

Tabel 1.3

Meninggalkan Kelas Sebelum Waktunya Tahun 2017 -2018

\begin{tabular}{|c|l|c|}
\hline NO & \multicolumn{1}{|c|}{ Kelas } & $\begin{array}{c}\text { Meninggalkan Kelas } \\
\text { Sebelum Waktunya }\end{array}$ \\
\hline 1 & Kelas X & 8 Peserta didik \\
\hline 2 & Kelas XI & 2 Peserta Didik \\
\hline 3 & Kelas XII & 10 Peserta didik \\
\hline \multicolumn{2}{|c|}{ Total } & 20 Peserta didik \\
\hline
\end{tabular}

Sumber: Buku Catatan Pelanggaran

Siswa Madrasah Aliyah At-Taufiq Singaraja

Dari Tabel $1.1 \mathrm{di}$ atas dapat dilihat bahwa bentuk perilaku membolos yang di lakukan peserta didik Madrasah Aliyah AtTaufiq yaitu meninggalkan kelas sebelum disaat kegiatan belajar sedang berlangsung. Dalam periode Agustus 2017-Maret 2018 dapat ditemukan 20 peserta didik.

Dari penjelasan di atas dapat dikatakan bahwa terdapat beberapa 
bentuk perilaku membolos yang dilakukan peserta didik Madrasah Aliyah At-Taufiq Singaraja yaitu, terlambat, tidak masuk sekolah tanpa izin dan pulang sekolah sebelum waktunya. Hal ini sesuai dengan Gunarsa (2006: 31) bahwa membolos adalah ketidakhadiran peserta didik tanpa adanya izin, pergi meninggalkan sekolah sebelum waktunya dan terlambat datang ke sekolah.

\section{Pola Penanganan Perilaku Menyimpang (Membolos) Di Madrasah Aliyah At-Taufiq}

Pola penanganan merupakan sebuah tindakan yang dilakukan untuk mengatasi sebuah permasalahan yang terjadi pada seseorang ataupun kelompok. Ada beberapa pola penanganan yang di lakukan Madrasah Aliyah At-Taufiq untuk mengatasi perilaku membolos yaitu: Pemberian sanksi atau hukuman. Hukuman atau sanksi yang di berikan Madrasah Aliyah At-Taufiq Singaraja terhadap peserta didik yang membolos sudah ditetapkan dalam peraturan tata tertib yang berlaku di sekolah. Di dalam tata tertib tersebut sudah ada sanksi-sanksi dengan sistem point bagi peserta didik yang melanggar tata tertib sekolah khususnya membolos.

Dalam hal mekanisme pemberian sanksi kepada peserta didik yang melakukan pelanggaran tata tertib. Pertama yaitu peringatan secara langsung oleh guru, yang kedua jika peserta didik melakukan pelanggaran lagi maka wali kelas yang memberikan bimbingan, kemudian langkah terakhir yaitu bimbingan yang dilakukan kepala Madrasah jika guru dan wali kelas tidak mampu memberikan efek jera kepada peserta didik yang melanggar tata tertib dan biasanya jika kepala Madrasah yang bertindak maka pelanggaran yang dilakukan peserta didik sudah melampaui batas skor yang ditetapkan.

Kemudian penanganan secara terapis. Penanganan secara terapis yang dilakukan Madrasah Aliyah At-Taufiq Singaraja dengan menerapkan pendekatan secara mendalam. Hal ini dilakukan agar peserta didik bisa lebih terbuka dengan guru mengenai permasalahan yang terjadi pada dirinya. Selanjutnya yaitu membayar denda sebesar Rp.2000 bagi peserta didik yang terlambat datang ke sekolah.

Dapat dikatakan bahwa Madrasah Aliyah At-Taufiq melakukan tiga tindakan dalam menangani peserta didik yang melakukan perilaku menyimpang dalam bentuk membolos yaitu, pertama tindakan preventif yaitu tindakan untuk mencegah kemungkinan terjadi pelanggaran-pelanggaran dalam hal ini tindakan yang dilakukan Madrasah Aliyah At-Taufiq adalah penerapan tata tertib sebagai pedoman perilaku peserta didik di sekolah. Kedua dengan tindakan represif tindakan yang dilakukan untuk memberikan sanksi sebagai kontrol sosial seperti diberlakukannya sistem poin pada setiap pelanggaran yang dapat menentukan besar kecilnya sanksi yang didapatkan, dan yang ketiga tindakan kuratif tindakan gabungan untuk pencegahan dan pemberian hukuman, misalnya terlambat dikenakan denda uang Rp.2000 dan membaca Surah Ar-Rahman yang ada dalam Al-Qur'an.

Hal ini sesuai dengan yang diungkapkan oleh Hisyman (2018: 169) pola penanganan perilaku menyimpang (membolos) terdapat tiga tahap yaitu, Tindakan preventif atau tindakan pencegahan, tindakan resprensif tindakan dengan menerapkan sanksi dan hukuman dan tindakan kuratif, tindakan gabungan yang digunakan untuk kontrol sosial seperti pemberian peringatan dan hukuman secara bersamaan.

Namun Meskipun pihak Madrasah sudah menerapkan pola penanganan untuk mengatasi peserta didik yang melanggar tata tetib, hal tersebut masih sangat kurang efektif, terbukti di lapangan bahwa masih banyak peserta didik yang melakukan tindakan membolos.

\section{Aspek-aspek Fenomena Membolos Yang Dijadikan Sumber Belajar Sosologi Di SMA}

1. Ranah Kognitif 
Ranah kognitif yaitu merupakan aspek yang berkaitan dengan pengetahuan, penalaran dan pikiran. Dalam kaitannya dengan $\mathrm{KI} 3$ yang sesuai dengan silabus Kementrian Pendidikan dan Kebudayaan Jakarta 2016) yaitu memanfaatkan hasil penelitian tentang fenomena membolos sekolah di Madrasah Aliyah At-Taufiq sebagai sumber belajar sosiologi di SMA, yaitu siswa dapat memahami, menerapkan, serta dapat menganalisisi alasan yang berkaitan dengan latar belakang peserta didik melakukan perilaku membolos, bagaimana bentuk-bentuk perilaku membolos yang dilakuan peserta didik dan pola penanganan yang dilakukan pihak Madrasah untuk meminimalisir perilaku membolos.

\section{Ranah Afektif}

Ranah afektif merupakan aspek berkaitan dengan sikap perasaan, emosi, dan reaksi yang berbeda dengan penalaran. Hal ini ini sesuai dengan apa yang ada pada Kompetensi Inti (KI) I dan II. Dalam menjelaskan mengenai KI I dan 2 di atas, menegaskan bahwa pemanfaatan fenomena membolos sekolah di Madrasah Aliyah At-Taufiq sebagai bentuk perilaku menyimpang dan potensinya sebagai sumber belajar sosiologi di SMA dapat dikaitkan dengan materi realitas sosial, dimana peserta didik mendapatkan pemahaman bahwasanya fenomena membolos ini dapat dijadikan contoh sebagai salah satu bentuk perilaku menyimpang pada sub bab penyimpangan sosial. Penyimpangan sosial sendiri merupakan segala bentuk perbuatan yang tidak sesuai dengan nilai dan norma yang ada di dalam masyarakat.

\section{Ranah Psikomotorik}

Dalam kaitannya dengan $\mathrm{KI} 4$ dengan fenomena membolos sebagai bentuk perilaku menyimpang dan sebagai sumber belajar sosiologi di SMA, yaitu peserta didik dapat mengaitkan realitas sosial dengan menggunakan konsepkonsep dasar sosiologi untuk mengenali beberapa ragam gejala sosial di masyarakat. Sesuai dengan penjelasan mengenai aspek-aspek di atas, penelitian ini mempunyai potensi sebagai sumber belajar sosiologi di SMA kelas $X$ dalam $\mathrm{Bab}$ ragam gejala sosial dalam masyarakat. Potensi yang dimaksud dipaparkan dalam bentuk Rancangan Pelaksanaan Pembelajaran (RPP).

\section{SIMPULAN DAN SARAN}

Berdasarkan data yang diperoleh maka dapat disimpulkan hasil dari penelitian ini sebagai berikut,

1. Faktor penyebab terjadinya perilkau membolos yang dilakukan peserta didik yaitu faktor yang berasal dari dalam diri peserta didik itu sendiri, dimana mereka malas untuk berangkat ke sekolah. Kemudian faktor eksteranal yaitu meliputi guru, teman dan sarana prasana yang minim.

2. Bentuk perilaku membolos yang terdapat di Madrasah Aliyah At-Taufiq yaitu terlambat, pulang sebelum waktunya, pergi meninggalkan kelas saat kegiatan belajar sedang berlangsung dan tidak masuk sekolah tanpa adanya izin yang jelas.

3. Pola penanganan yang dilakukan Madrsah Aliyah At-Taufiq yaitu pertama dengan menerpakan hukuman atau saknsi yang sudah tertulis jelas di tata tertib sekolah. Kemudian yang kedua melakukan pendekatan secara terapis, dimana guru melakukan pendakatan secara mendalam teradap peserta didik yang sering melakukan perilaku membolos. Dan yang ketiga yaitu diterapkannya denda sebesar Rp.2000 bagi peserta didik yang datang terlambat ke sekolah. Namun penanganan yang di lakukan Madrasah masih belum bisa meminimalisir perilaku membolos peserta didik.

4. Adapun aspek-aspek dalam penelitian ini yang digunakan untuk membahas hasil penelitian yang memiliki potensi sebagai sumber belajar sosiologi yaitu, ranah afektif, kognitif, dan psikomotorik. Dengan aspek-aspek tersebut dapat mengetahui hasil penelitian yang berpotensi sebagai sumber belajar dalam bentuk rencana pelaksanaan pembelajaran (RPP) dengan 
Bab ragam gejala sosial di masyarakat yang terfokus pada materi penyimpangan sosial.

Berdasarkan hasil penelitian yang dilakukan oleh peneliti di lapangan, ada beberapa temuan yang ingin disampaikan penulis sebagai terkait dengan penelitian yang dilakukan, yaitu

a. Bagi guru, dengan menggunakan sumber belajar yang monoton sehingga dapat membuat peserta didik tidak dapat memahami sumber yang lain sehingga rasa keingin tahuannya tidak berkembang. Seharusnya dalam kegiatan belajar mengajar guru dapat memberikan contoh yang berada di sekitar peserta didik agar peserta didik dapat memahami dan mempunyai kepekaan terhadap lingkungan sekitarnya.

b. Bagi peserta didik, di harapkan tidak hanya berfokus pada sumber belajar seperti buku paket dan LKS tetapi peserta didik harus lebih dekat dengan lingkungan sekitar agar tidak mengabaikan fenomenafenomena sosial yang ada di lingkungan tempat tinggal utamnnya, sehingga pemahaman peserta didik tidak hanya ituitu saja.

\section{UCAPAN TERIMAKASIH}

Dalam penelitian ini, peneliti mengucapkan terima kasih kepada Rektor Undiksha, Bapak Dekan FHIS, Ibu Dr. Luh Putu Sendratari, M.Hum selaku Dosen Pembimbing I, Bapak Dr. I Ketut Margi, M.Si selaku Dosen Pembimbing II, Ibu Dr. Tuty Mariyati, M.Hum, selaku Dosen Penguji, Kepala Madrasah Aliyah At-Taufiq Singaraja, Staf Guru Madrasah, dan para peserta didik Madrasah Aliyah At-Tufiq Singaraja yang telah bersedia memberikan data yang dibutuhkan, serta pihak-pihak yang tidak bisa disebutkan satu per satu yang telah memberikan kontribusi besar dalam penelitian ini.

\section{Daftar Pustaka}

Adipurnomo, Haryono. 2006. Sumber dan Media Pembelajaran. Departemen Pendidikan Nasional.

Gunarsah, Singgih. 2006. "Psikologi Untuk
Membimbing". Jakarta: PT BPK Gunung Mulia.

Hisyam, Ciek Julyati.2018. "Perilaku Menyimpang Tinjauan Sosiologis". Jakarta: Bumi Aksara.

Musfiqon. 2012. Pengembangan Media \& Sumber Pembelajaran. Jakarta: PT. Prestasi Pustakarya.

Prayoitno, dan Amti Ermar.2004. Dasar Dasar dan Bimbingan Konseling. Jakarta: PT.Rajagrafindo Persada.

Sanjaya, Wina. 2009. Strategi Pembelajaran Berorientasi Standart Proses Pendidikan. Jakarta: Kencana.

Sugiyono. 2010. Metode Penelitian Pendidikan. Bandung: Alfabeta.

Tutiona, Yoan Marti dan Abdul Munir.2016. Upaya Mengurangi Perilaku Membolos Melalui Konseling Individual Dengan Teknikl Behavior Contract Pada SMP Negeri 6 Palu. Jurnal Konseling dan Psikoedukasi Vo.1 No.1. 